\title{
Yeni Turistik Ĕgilimler: Antalya İli Örneği
}

\author{
Betül GARDA* Süleyman KARAÇOR**
}

\begin{abstract}
$\ddot{O} Z$
Günümüzde, gittikçe artan sayıdaki kişi, alışılmamış destinasyonlarda, adrenalini yükselten fiziksel ve zihinsel etkinliklere katılma arayışındadır. Bu yeni eğilimlere sahip turistler, yabancı olduğu bölgelerde yeniden keşfetmeyi ve kültürel değişimi yaşama firsatı yakalayabileceği, heyecanl ve orijinal tatilleri tercih etmektedirler. Dolaylsiyla seyahat harcamalarının büyük bir kısmını bu yönde kullanma eğilimindedirler. Bu sebeple, turizm işletmelerinin etkinliğinin, değişen turist beklentilerine göre çeşitlendirilen ürün yelpazesiyle artırılabileceği gözlemlenmektedir.

$B u$ araştırmada, günümüzde, turistik tüketicilerin değişen beklentileri kavramsal çerçevede incelenmiştir. Ayrıca, yeni turist tipinin demografik ve sosyo-ekonomik yapılarının, tercih edilen turistik faaliyetlere etkisi değerlendirilmiştir. Bu çalışma, turizm pazarlaması alanında yapılacak araştırmalara faydalı olması amacıyla hazırlanmıştır.
\end{abstract} Pazarlamast

Anahtar Kelimeler: Yeni Turist Özellikleri, Turizm Pazar Bölümlendirmesi, Turizm

JEL Sinıflandırmast: M31

\section{New Touristic Tendency: A Sample Of Antalya}

\begin{abstract}
In the information age, an increasing number of people is seeking to participate the physical and mental activities, which raise the adrenaline in unusual destinations. Tourists in this trends are preferred the experience opportunity for having the exciting and original holidays to rediscover and cultural changes in the foreign regions. Therefore, a large portion of travel expenses are tend to use in this direction. For this reason, the effectiveness of tourism businesses can be enhanced by diversifying the range of products according to the expectations of tourists is observed.

In this research, touristic consumers' changing expectations have been examined in a conceptual framework. In addition, this study investigated the effect of new tourists' demographic and socio- economic structures on the touristic activities. This implications highlight for the future researches in the tourism marketing.
\end{abstract}

Key Words: New Tourist, Tourism Market Segmentation, Tourism Marketing

JEL Classification: M31

\section{GİRIŞ̧}

Turizm endüstrisindeki tüketici davranışı modeli sürekli değişmektedir. Günümüzün 'yeni turist'leri denenmemiş tatil deneyimleri arayan daha tecrübeli seyahatçiler olduğu gözlemlenmektedir (Weber, 2001: 363). Artık sıradan ve alışılagelmiş tatillerden farklı deneyim tatilleri potansiyel turistlere daha çekici gelmektedir. Bu tip turistler, seyahat için ayırdıkları gelirlerinin önemli bir miktarını heyecan ve macera için harcamaktadır (Williams ve Soutar, 2005: 248; Kane and Tucker, 2004: 219; Ryan, 2002: 21; Lepp ve Gibson, 2008: 742). Yeni

\footnotetext{
* Yrd.Doç.Dr. Selçuk Üniversitesi Sosyal Bilimler Meslek Yüksekokulu, Pazarlama ve Reklamcılık Bölümü. bgarda@gmail.com

** Prof.Dr.Selçuk Üniversitesi İletişim Fakültesi, Reklamcılık Bölümü skaracor@ selcuk.edu.tr 
turist tipini bu davranış farklılığına yönelten ve bu macera arayışının en önemli nedeni bireyin kişisel gelişimini sağlama ve öz saygıyı kazanma arzusudur (Page vd, 2005: 385; Sung, 2000). Örneğin; turistler, katıldıkları etkinliklerde yeri geldiğinde risk almak ve fiziksel/zihinsel mücadeleyi kazanmak istemektedirler. Ayrıca farklı ve adrenalini yükselten deneyimler arayanların sayısı da oldukça fazladır. Dolayısıyla sunulan turistik hizmetlerin çeşitliliğinden kaynaklanan doygunluk, kişileri farklı olanı aramaya itmektedir.

Benzer şekilde, ekonomik, sosyal ve kültürel değişim toplumsal yaşamda tüketim kalıplarını değiştirmektedir. Çağdaş toplumlarda, bireylerin sağlıklı yaşam biçimini benimsenmesi, doğaya karşı yükselen hassasiyet ile kalite bilinçli tüketimin daha fazla istenen unsurlar olması bu değişime örnek olarak kabul edilebilir. Bu tarz değişimler ayrıca bireylerin tatil alışkanlıklarını değiştirerek, daha aktif katılıml tatilleri tercih etmelerine neden olmaktadır (Sung vd, 2001: 48; Page vd., 2005: 382). Dikkat çekici diğer bir eğilim ise insanların yaşamında boş zamanlarını değerlendirme biçimleri ile ilgilidir. Şüphesiz turizm talebine çeşitli şekillerde olumlu etkisi olan "boş zaman", günlük yaşamımızın da önemli bir unsuru haline gelmiştir. Bu tip boş zaman etkinliklerine katılım için teşvik edilmiş kişiler, katılımlarının günlük yaşamda var olan deneyimlerinden farklı olmasını beklemektedirler. (Aktaran: Cater, 2006: 317).

\section{YENİ TURISTIKK EĞILIMM}

Son dönemde 'yeni turist' olarak değerlendirilen turistler, tatil deneyimlerini daha önemli faydalar elde etmek için gerçekleştirmek istemektedirler. Yeni turist tiplemesi şekil 1'de gösterildiği gibi bir takım ayırıcı özelliklere sahiptir. Yeni turistin ana özelliklerinden biri; günlük yaşamın monotonluğundan uzaklaşıp, değişik biçimlerde kendini gerçekleştirmeyi başarabilme ihtiyacıdır. Turistik deneyimlerinin çoğunda amaç; günlük yaşamdan belli bir süre uzaklaşmaktır. Uzaklaşma ihtiyacı belli bir süre için ev yaşantısından ve stresinden kaçıp, gerçekten tatilde olduğunu hissetme arzusu tarafindan tetiklenmektedir (Lepp ve Gibson, 2008: 742; Cater, 2006: 318; Ferguson ve Todd, 2005: 150). Yeni turistik eğilimde, bu tip aktif katılımlar sonucu günlük yaşantıdan kaçışı içermektedir. Örneğin; Amazon ormanlarında bir nehir gezisi, Gobi çölünde deve ile yolculuk ya da Avustralya'da yunuslarla yüzmek bireylere çekici gelmektedir. Bu uzaklaşma arzusu, ayrılmaz bir şekilde 'tepe deneyimler'(Maslow, 1976) ile bağlantılıdır. (Gyimothy ve Mykletun, 2004: 857).

"Kendini gerçekleştirme" eğilimi, bireylerin yaş ve yaşam tarzı ile yakından ilişkilidir (Swarbrooke vd, 2003: 60-61; Richards ve Wilson, 2006: 41; Pearce, 1992: 13). Örneğin, Berno ve diğerlerinin (1996) Yeni Zelanda da 651 turiste uyguladıkları anket sonucuna göre, kişinin yaşı seyahat katılımında önemli bir etkiye sahiptir. Bu araştırmada, 20-34 yaş gruplarının, bunge jumping, rafting, jet skiing, kayak ve dağcılık gibi turistik etkinliklere diğer yaş gruplarına göre daha fazla ilgi gösterdikleri tespit edilmiştir. 45 yaş üstü grup sözü edilen etkinliklerle uğraşmak için kendilerini çok yaşlı bulmaları nedeniyle ilgi göstermemektedir. Ayrıca, Loverseed'de (1997: 91-92) fiziksel güce dayanan etkinliklere katılım ile 
ilgili olarak "yaş ve kişisel tercihlerin" önemli bir faktör olduğunu savunmaktadır. Fiziksel çaba gerektiren sportif tatillerin seçiminde, fiziksel sağlık ve zindelik diğer etkin bir faktör olarak kabul edilmektedir (Lepp ve Gibson, 2008: 742; Page vd, 2005: 382-383).

Şekil 1. 'Yeni Turist' Özellikleri

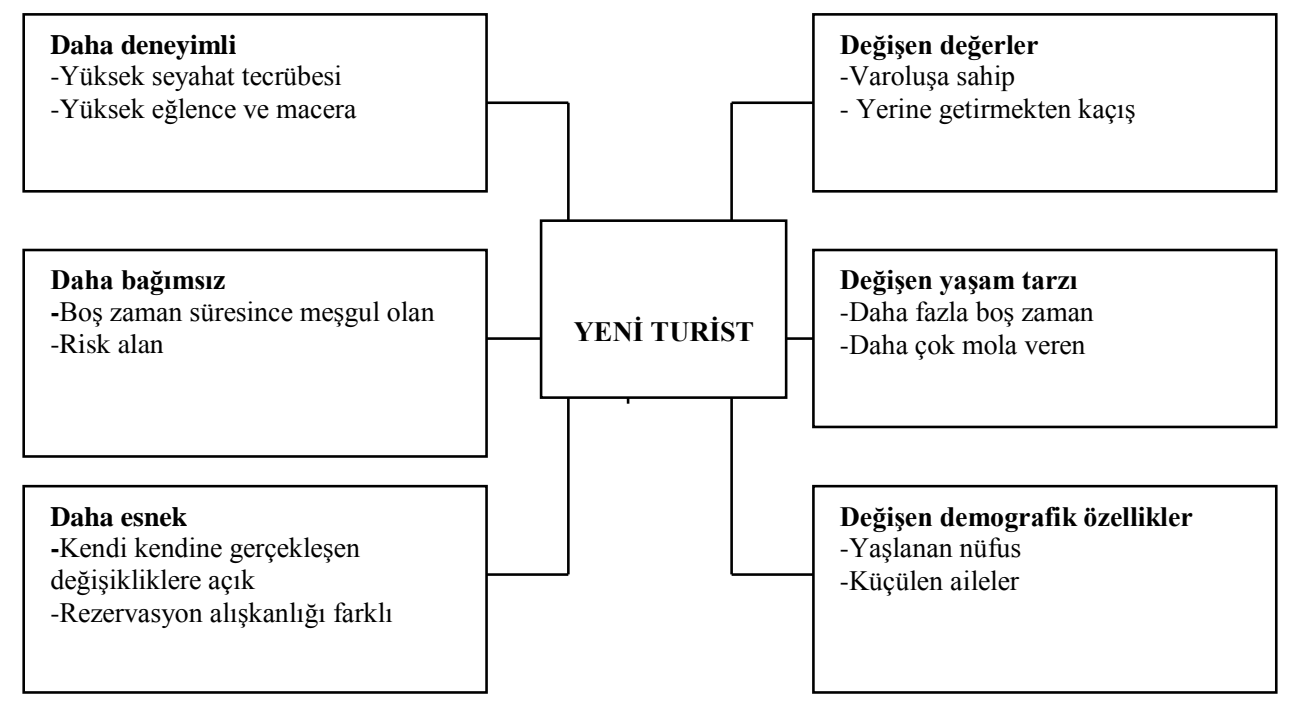

Kaynak: Swarbrooke, John, Beard, Colin, Leckie, Suzanne and Pomfret, Gill (2003). Adventure Tourism: The New Frontier. USA: Elsiver Science Ltd, p: 59.

Dolayısıyla, hem yaş hem de yaşam tarzı günümüz yeni turistlerinin karar alma süreci üzerinde önemli bir etkiye sahiptir. Ayrıca fiziksel çabaya dayalı turistik etkinliklerinde bireylerin sağlık durumları ve deneyimleri de yaş kadar etkili bir faktör haline gelmektedir. Fiziksel çabaya dayanmayan turistik etkinliklerinde ise bireyin bulunduğu yaş grubunun belirgin bir etkisi bulunmamaktadır. Sonuç olarak tüketici davranışının yapısındaki daha sağlıklı yaşam tarzı ve günlük yaşamla tezat içinde olan tatil deneyimleri arayışı yönündeki değişim, aktif katılımlı turistik etkinliklere talebinin artmasına neden olmaktadir.

Swarbrooke $(2003,59)$, yeni turist özelliklerinin esas unsurlarını aşağıdaki şekilde olması gerektiğini iddia etmektedir. Bunlar;

- Benzer ve tahmin edilebilir zevklere sahip olan,

- Seyahati bir yenilik olarak kabul eden,

- Sicak destinasyonları tercih eden,

- Turist hizmetlerinin kalitesine az önem veren,

- Tatili sadece çalışma ya da günlük yaşamın monotonluğundan uzaklaşmak kabul eden bireylerdir.

Günümüzde, turistler, genel olarak düşük risk alanlar ve yüksek riski benimseyenler olmak üzere iki gruba ayrılmaktadırlar. Düşük risk (soft) alan 
turistler, genellikle, algılanmış riski bulunan fakat düşük seviyede gerçek riske sahip başlangıç seviyesindeki etkinliklerde yer almaktadırlar (Hill, 1995: 63; Williams ve Soutar, 2005: 248-250). Bu turistler genellikle acemidir ve önceden tecrübeleri olmadığ1 ya da riski düşük olduğu için güvenlikli etkinlikleri tercih ederler. Düşük risk alan turistler kendini keşfetme, rutin kentsel yaşamdan kaçma ve yeni çevrelerde deneyim kazanma, heyecan yaşama, yenilik, kontrollü bir çevrede sosyalleşme firsatı gibi nedenlerle seyahat etmektedirler (Morgan ve Fluker, 2006: 154; Williams ve Soutar, 2005:248; Bentley vd., 2003: 86; Page vd, 2005: 382; Pomfret, 2006: 118).

Diğer taraftan yüksek risk alan turistler üst seviyede tecrübe gerektiren yüksek derecede riskli etkinlikleri tercih ederler (Hill, 1995: 63). Bu tip turistler fiziksel olduğu kadar yüksek deneyim ve yetenek gerektiren zihinsel açık hava mücadelelerine de katılırlar (Morgan ve Fluker, 2006: 154). Yüksek risk alan turistler, yüksek adrenalin isterler. Bazen yüksek deneyimlerinden dolayı riski kontrol edebildikleri gibi, bazen de kontrol edemezler. Bu turistlere başlica çekici gelen etkinlikler; dağcılık, su kayağı, kanoculuk, balta girmemiş ormanlarda safari, Afrika'daki az ziyaret edilen vahşi yaşamı izleme olarak sayılabilir (Williams ve Soutar, 2005:248; Page vd, 2005: 385).

Düşük ve yüksek riskli turistik etkinliklerin tercih edilme düzeyi üzerinde, katılımciların karakteristik, motivasyon, beceri ve deneyim niteliklerinin de etkisi bulunmaktadır. Düşük ve yüksek riskli turistik etkinliklere katılımın artması, bireysel becerileri artıracak; dolayısıyla bireyler daha yüksek seviyelerde uyarımı ve daha riskli uğraşlara katılımı tercih edeceklerdir (Kane and Tucker, 2004: 220; Cater, 2006: 321; Page vd, 2005: 383 ).

Swarbrooke ve diğerleri (2003: 64) potansiyel turistler arasında düşük riskli turistik etkinliklerin, yüksek riskli olanlara göre daha yüksek oranda tercih edildiğini gözlemlemişlerdir. Yüksek risk alan turistler daha fazla deneyim edinmek ve etkinliklerde daha fazla cesaret göstermek durumundadır. Düşük riskli turistler ise, etkinliklere aktif katılım isteği olan fakat az deneyimleri olan bireylerdir.

Ayrıca yeni turistler çok farklı nedenlerden dolayı düşük ya da yüksek riskli etkinliklerde yer alabilirler. Birinin riskli olarak algıladığı etkinlik, diğeri için risk niteliğinde olmayabilir. Tuson'a (1994) göre, kişinin mücadele gücü ve panik limiti seçeceği turistik etkinlik tipini belirlemektedir. İnsanların kişiliği ve önceki deneyimleri risk algisın1 etkilemektedir (Weber, 2001: 367-368; Page vd, 2005: 383). Örneğin goril izleme tatili seçen vahşi yaşam turları deneyimine sahip bir turist, yüksek derecede zihinsel mücadele gerektiğini tahmin edecek ve gorili yakından gördüğü zaman heyecanını kontrol edecektir. Vahşi yaşam turlarında deneyimsiz olan ve aynı tatili seçen turist ise gorili gördüğünde panikleyip kontrolünü kaybedebilir (Swarbrooke vd, 2003: 65).

Bazıları, kendi tolerans alanlarının içinde kontrol edebildikleri etkinlikleri tercih ederken, diğerleri fiziksel ve zihinsel mücadele gerektiren, dayanma kapasitelerinin yükselten daha yüksek riskli seyahatlere meyillidirler. Buna, kuş 
izleme turlarına katılan bir turist ile Everest'e tırmanan dağcının tercih ve macera anlayışı farklı örnek olarak verilebilir. Breivik (1996) Everest'e tırmanan dağcılar hakkında yaptığı araştırmada, turistleri bu seyahate sevk eden karakter özelliklerinin düşük seviyede endişe, dayanıklılık, isteklilik ve duygusal kararlılık olduğunu tespit etmiştir. Bu tip kişilik özelliklerine sahip bireyler yüksek riskli turistik etkinlikler ile uğraşmaya daha meyillidir. (Buckley, 2009: 220; Pomfret, 2006: 118). Örneğin; 'uçan balonla seyahat etme' düşük riskli bir etkinlik olarak kabul edilirken, bu etkinliği ilk kez deneyecek biri için oldukça riskli görünüp paniklemesine neden olabilir. Bu kişinin bakış açısına göre uçan balon riskli bir maceradır (Pearce, 1995: 41; Swarbrooke vd, 2003: 65).

\section{YENI TURIST TIPININ MOTIVASYONLARI}

Yeni turistler, içsel ihtiyaçlarını tatmin edebilmek için çeşitli tatil deneyimleri aramaktadırlar. İnsanlar öz itibariyle tatilden zevk almak istemektedir. Bunun nedenleri (Tangeland ve Aas, 2009: 823; Weber, 2001: 363); rahatlama ihtiyac1, itibar kazanma, sosyalleşme, kişisel gelişim, farklı bir şeyler yapma arzusu, heyecan, macera, farklı yaşam biçimlerini ve kültürleri tanıma arzusu, benzer zevklere sahip insanlarla tanışma ve entelektüel zenginleşme şeklinde sayılabilir.

Başlangıçta, birey günlük yaşamın monotonluğundan uzaklaşmak istediğinde esas olarak üç farklı seçeneği bulunmaktadır. Bunlar; yerel bölgedeki herhangi bir boş zaman etkinliğine katılmak, akraba ya da arkadaşlarını ziyaret etmek ve son olarak iş amaçlı bir seyahate çıkmaktır. $O$ halde, boş zaman deneyimlerinin doğasını biçimlendiren spesifik güdüler, sosyo-psikolojik faktörler (itici faktörler) ve kültürel faktörler (çekici faktörler) biçiminde ikiye ayrılabilir. Dann (1977), geçmiş güdü dizisinin seyahat ihtiyacını belirlerken, sonraki duygulanımın ise hedef bölge seçiminde etkili olacağını ileri sürmektedir (Ferguson ve Todd, 2005: 150; Kane and Tucker, 2004: 220).

Pek çok teorik çerçevede turist motivasyonları açıklanmaya çalışılmıştır. Pearce (1988) macera seyahati konusunda, Maslow (1976) hiyerarşisinden uyarlanan, bir seyahat hiyerarşisi geliştirmiştir. 'Seyahat kariyer merdiveni' (travel career ladder) olarak adlandırılan "macera turizmi hiyerarşisi" (Garda, 2014), bireysel turist davranışı temeline kurulmuştur. İnsanlar tatilleri süresince yüksek düzeydeki istek ve ihtiyaçlarını karşılamaya çalışmaktadırlar (Gyimothy and Mykletun, 2004: 857; Swarbrooke vd, 2003: 67).

Pearce'ye (1992:13) göre, bu teori içsel ve dişsal motivasyonları göstermektedir. Seyahat Kariyer Merdiveni, seyahat için turistlerin çoklu model ya da güdülerinin, tek bir güdüden daha etkin olduğunu vurgulamaktadır. Şekil 2 de gösterilen beş aşamadan oluşan seyahat kariyer merdiveninde; biyolojik ihtiyaçlar (rahatlama), güvenlik ihtiyaçları ( uyarım derecesi), gelişim ve büyüme ihtiyaçları, özel ilgi ve kişisel gelişim ihtiyaçları ve en üst seviyede ise şiddetli katılım ihtiyaçları ( kendini gerçekleştirme) bulunmaktadır.

Seyahat Kariyer Merdiveni, turistlerinin çoğunluğu en üst seviyedeki ihtiyaçlarını giderme çabasındadırlar. Turistik deneyimler ile kendini gerçekleştirme seviyesindeki hayallerin gerçekleştirilmesi ya da içsel barış ve 
uyuma ulaşılması sağlanacaktır. Bu motivasyon seviyesi hem fiziksel hem de zihinsel etkinlikleri tercih eden turistler için geçerlidir (Ferguson ve Todd, 2005: 150-151; Swarbrooke vd, 2003: 68: Weber, 2001: 362).

Sonuçta, motivasyon seyahat kararında ve turist davranışlarında belirleyici bir rol oynamaktadır. Buna rağmen, turistleri etkileyen kişilik, finansal durum, sağlık sorunları ve seyahat arkadaşları gibi diğer faktörlerin etkisini de göz ardı etmemek gerekir (Pearce, 1993: 24). Turistik tüketici için en temel motivasyon unsurları; risk alma, heyecan arayışı ve başarı arayışı şeklinde sıralanabilir. $\mathrm{Bu}$ motivasyon unsurları kişinin faklı seyahat seçeneklerine olan ilgisini artıracaktır. $\mathrm{Bu}$ unsurlar aşağıdaki şekilde açıklanabilir:

Şekil 2. Seyahat Kariyeri Merdiveni (Pearce, 1988)

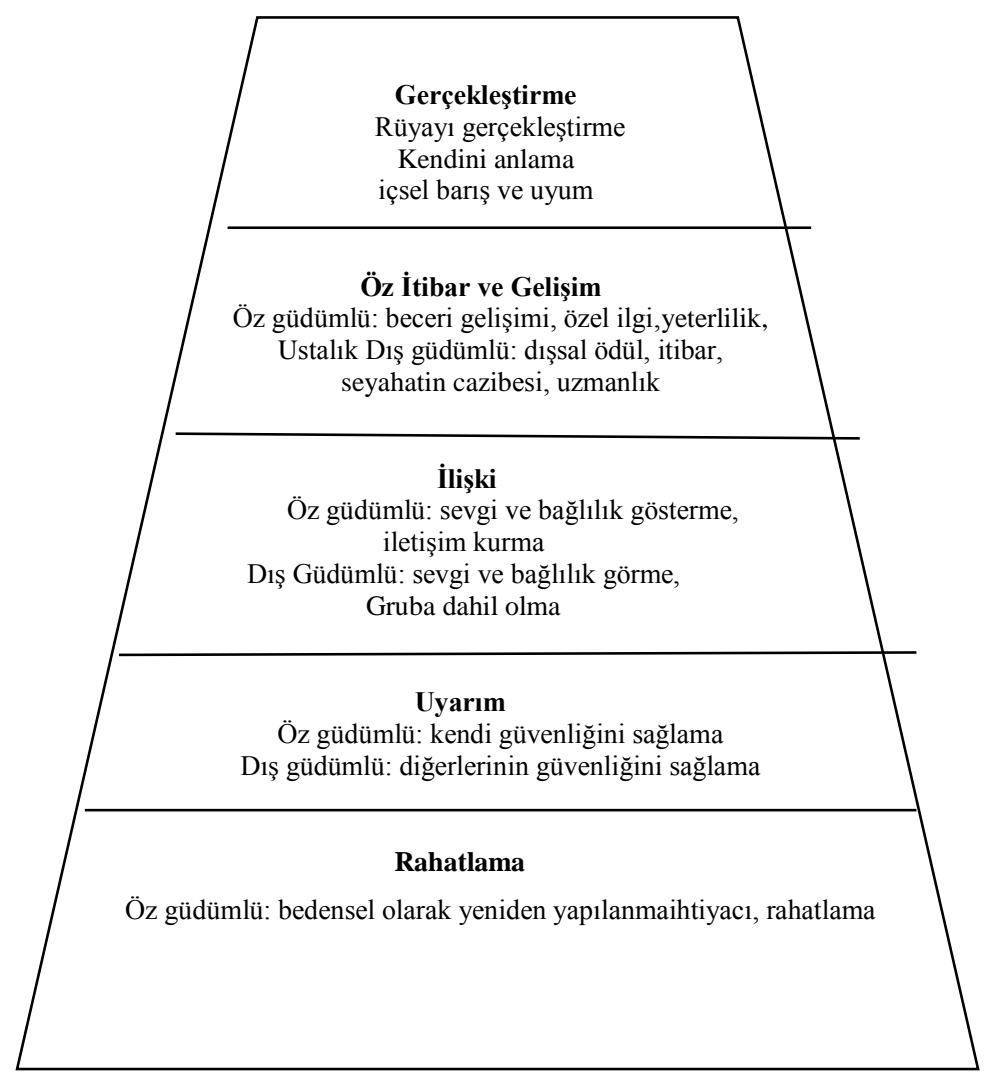

Kaynak: Swarbrooke, John, Beard, Colin, Leckie, Suzanne and Pomfret, Gill (2003). Adventure Tourism: The New Frontier. USA: Elsiver Science Ltd, p: 68.

\section{A. Risk Alma}

Risk, yeni turist tipi için güçlü bir güdüdür. Her etkinlik, belli miktarda riske sahiptir. Seyahat türünü seçerken, deneyimin sonuçları kesil değildir ve risk 
tahmin edilemez. Böylece risk kişinin maceradan hoşlanmasında belirleyici bir rol oynayacaktır. Aslında bir deneyimde riskin bulunmaması tatmin düzeyinin düşmesine ya da katılım dürtüsünün kaybolmasına neden olacaktır. Riskli deneyimler üzerine yapılan pek çok araştırmalar açık hava rekreasyonları alanından ortaya çıkmaktadır. Bu tip araştırmalar, risk aramanın, herhangi bir maceracı turistik seyahatin ayrılmaz bir parçası olduğu ilkesine dayanmaktadır (Morgan ve Fluker, 2006: 155; Sung ve diğerleri, 1997; Kane and Tucker, 2004: 220).

Şekil 3. Risk Bileşenleri

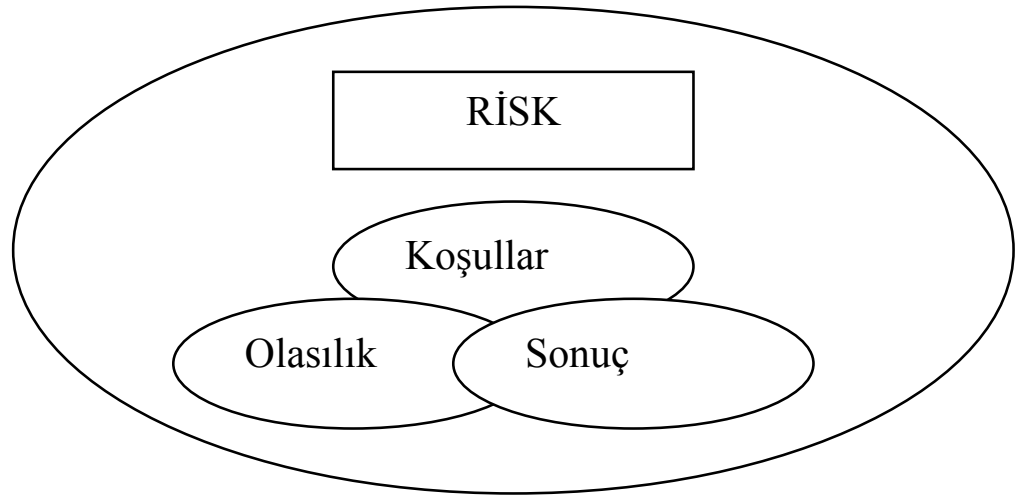

Kaynak: Ryan, Chris (2003). Risk Acceptance in Adventure Tourism. (Edited by Jeff Wilks and Stephen J. Page). Managing Tourist Health and Safety in the New Millenium. UK: Elsevier Science Ltd, p. 56

Elms (1998), şekil 3'te görüldüğü gibi risk bileşenlerini; koşullar, olasılık ve sonuç olarak üçe ayırmaktadır. Risk alan turistler, uğraşılarının sonucunu psikolojik açıdan bir ödül olarak kabul ederler. Risk almak kaybetme ihtimalinin olumsuzluğuna rağmen; uzun vadede coşku içeren, adrenalini artıran ve mutluluk veren bir faktör olarak karşımıza çıkmaktadır. Turistler tatil sürecince risk alarak, etkinliğe ilgi düzeylerini yükselteceklerdir. Psikolojik açıdan risk alma: günlük sorumluluklardan uzaklaşma eğilimi olarak değerlendirilirken; sosyal açıdan: belli bir kurumda çalışmanın ödülü olarak, çalışma dışı boş vaktin değerlendirmesi olarak değerlendirilebilir. Böylece uğraşılan etkinlik ve mekan basit bir şekilde sosyal açıdan anlamlandırılmış olur (Aktaran: Ryan, 2003: 56; Cater, 2006: 319; Page vd, 2005: 385).

Risk kavramının en karmaşık bileşeni 'olasılıktır'. Teknik olarak risk bir olayın gerçekleşme ihtimali olarak ifade edilemez. Fakat kaybetme olasılığının önemi de göz ardı edilemez. Olasılık, bir eylem ya da olayın gerçekleşmesidir. Genel manada ise olasılık: risk almaktan elde edilecek faydayı işaret etmektedir. Tatil şartlarında olasılık, riskin teknik anlamını taşımayan, sadece turistlerin etkinliklere katılımlarını etkileyen algılanan bir bileşen olarak karşımıza 
çıkmaktadır. Örneğin, günlük yaşamda aşırı miktarda alkol aldıktan sonra araba kullanılırsa, bu bir kaza ile ya da ehliyete el konulmasıyla sonuçlanabilir. Boş zaman bağlamında ise örneğin bir dalgıçlık kursu ya da bir tırmanış gezisi başarı ile bitirilememişse, bundan dolayı kişi kendine olan saygısını kaybedebilir (Ryan, 2003: 57; Swarbrooke vd, 2003: 71).

Risk, olumsuz bir anlam çağrıştırmasına rağmen, olumlu sonuçları olan bir uğraştır. $\mathrm{Bu}$ olumlu sonuçlar potansiyel turistleri aktif katılımlı etkinliklere katılmaya yönlendirmektedir (Ewert, 1989). Mesela; Amazon ormanında dağ yürüyüşü turuna katılan bir maceracı, bu gezi süresince zehirli bir yılan 1sırması, susuz kalma ya da bir vahşi hayvanın saldırısına uğrama gibi çeşitli risklerle yüz yüze gelir. Tatilin sonunda ise, kişi kendini gerçekleştirme ve riskli bir maceradan sonra hayatta kalma tatminini hissedebilir.

Risk iki kategoride incelenebilir: kişinin kontrol edebildiği ve mücadele olarak algıladığı 'olumlu risk'; kişinin kontrol edemediği ve tehlike olarak algıladığı 'olumsuz risk' (Deniz ve Erciş, 2008: 307). Bu risk kategorileri, ayrılmaz bir şekilde, bireyin yetenek, deneyim ve macera etkinliği hakkındaki bilgisiyle bağlantılıdır. Johnston (1992), Yeni Zelanda'da dağcılıkla ilgilenen macera rekreasyonu hakkında yaptığı araştırmasında dağcılık etkinlikleri üzerinde deneyimli olan bu bireylerin riski, tehlikeden çok mücadele olarak algıladıklarını tespit etmiştir. Dağcılık maceralarının içerdiği riski, korkutucu bulmak yerine, eğlence düzeylerini yükseltecek olumlu bir unsur olarak görmektedirler. Buna göre, dağcılık maceralarında tecrübe olmayan biri için bu etkinlikler kontrol edilemeyen derecede risk içerir. Ancak, bu kişi deneyim kazanmaya başladığ zaman, dağcılığın içerdiği riske karşı olumlu bir bakış açısı geliştirecektir (Aktaran: Swarbrooke vd, 2003: 71).

Çoğunlukla macera katılımlarıyla ilişkili kişinin algıladığı risk ve fiili/gerçek risk arasında bir ayrım bulunmaktadır. Riskin objektif olmasına örnek olarak, spesifik etkinlikler için rapor edilen gerçek kaza sayısı verilirken; riskin sübjektif olmasına, katılımcının algıladığ 1 riskin büyüklüğü örnek olarak verilebilir. Cater'in (2000) araştırmasına göre, insanlar sıklıkla objektif riskin farklı bedensel maceracı etkinlikleri içerdiğini anlayamaz ve bu, etkinliğin riskin yüksek algılanmasından dolayı ret edilmesiyle sonuçlanır.

Özetlersek, risk hem olumlu hem de olumsuz yönde değerlendirilebilir. İnsanların riski nasıl algıladıkları, deneyim derecesine ve etkinlikte aldıkları role bağlıdır. Ayrıca, kişilik daima insanların riski algılamasında önemli bir etkiye sahiptir.

\section{B. Heyecan Arayışı}

Risk unsuru ile birbirini tamamlayan çok sayıda diğer güdülerden biri heyecan arayışıdır. Zuckerman (1979: 13), bu güdüyü, 'heyecan arayışı ölçeği' ile açıklamıştır. Heyecan arayış ölçeği (SSS), psikolojik bir model olup, insanların çeşitli durumlarda risk alma davranışlarını çözümlemektedir. Model, yirmi yıldan beri tüketici davranışındaki değişiklikleri de değerlendirmeye almaktadır. 
Geçerliliği pek çok çalışmada ortaya konulmaktadır (Willig, 2008: 692; Lepp ve Gibson, 2008: 740; Ryan, 2003: 60).

Zuckerman (1979: 13) heyecan arayış kavramını şu şekilde açıklamaktadır: 'değişiklik, yenilik, karmaşıklık ve yoğun heyecan arayışı nedeniyle bu tip bir deneyim için fiziksel, sosyal, finansal ve yasal risk almaya gönüllü olmaktır.'

Heyecan arama kavramı macera turistlerine uygulandığında, bu insanların fiziksel macera tatilleri ile ilgili riskli spor katılımcılarıyla benzer kişilik karakteristiklerini taşıdıkları varsayılabilir. Fiziksel olmayan macera katılımcılarının ise heyecan arayışı ölçeğinde (SSS) yüksek skorlu dezinhibisyon ve deneyim arayışı unsurları gibi turistik deneyimler aradığ düşünülebilir. Bu tip etkinlikleri tercih eden insanlar hız ve tehlike içeren riskli etkinliklerle uğraşmak için büyük istek taşımaktadır. Ayrıca, uygun olmayan yaşam tarzlarına ve seyahat etmeye de meyillidirler (Cater, 2006: 321).

Bulgular can sıkıntısı hassasiyeti ve dezinhibisyon alt ölçekleri arasında önemli bir farkın olmadığını göstermiştir. Diğer bir ifadeyle, karasal seyahatçiler ve kontrol katılımcıları sosyal uyarım için benzer isteklere sahiptir ve tekrar eden durumlara karşı benzer isteksizlikleri gösterirler (Lepp ve Gibson, 2008: 74).

\section{Başarı Arayışı}

Yüksek adrenalin, insanlar riskli turistik etkinliklere katıldığı zaman, yoğun heyecan arayışına katkıda bulunmaktadır. Adrenalin, insanların deneyimlerini kontrol eden önemli bir unsurdur. Örneğin dağ tırmanışında dağcıların adrenallin seviyesinin yükselmesi tırmanmaya daha fazla odaklanmalarını sağlamaktadır. Adrenalin spor ile ilgili becerilerin yükselmesine yardımc1 olmaktadır. (Page vd, 2005: 385).

Risk alma ve heyecan arayışının, macera rekreasyonlarından zevk almak için gerekli birer unsur olarak görünmesine rağmen, insanları bu tip etkinliklerle uğraşmaya yönelten farklı güdüler de bulunmaktadır. Sung ve diğerlerinin (1997) belirttiği gibi öz sayg1, bu etkinliklerde daha fazla beceriye sahip olma, yeni becerilerini geliştirme, yeni durumları tecrübe etmek gibi çeşitli ihtiyaçlar tarafindan da motive edilebilir (Sung vd, 1997; Elsrud, 2001: 602; Cater, 2006: $321)$.

Kişinin belli bir turistik etkinlikte sahip olduğu deneyimin derecesi ve motivasyonunun değişimi arasında karşılıklı bir ilişki bulunmaktadır (Pomfret, 2006: 117). Örneğin, scuba diving'de daha tecrübeli hale gelen insanlar, daha fazla heyecan hissetmek için daha uzun gezilere katılma isteği duyacaktır (Morgan ve Fluker, 2006: 155).

Fluker ve Turner (2000: 387-388) çalışmalarında motivasyonun değişikliğinin, doğrudan tecrübenin artmasıyla ilişkili olduğunu ispatlamıştır. Rafting yapan tecrübeli ve tecrübesiz kişilerin ihtiyaç, istek ve beklentilerini birbiriyle karşılaştırarak yaptıkları araştırmada, tecrübeli rafting yapanların daha rahat ve raftingden elde edecekleri sosyalleşme ve doğal çevrede daha fazla kalma gibi farklı faydalarla ilgilendiklerini tespit etmişlerdir. Aksine, tecrübesiz olan 
katılımcıların ise, yenilik, sporla ilgili heyecan ve amaçlarını başarabilmek için risk almaya daha eğilimli olduklarını gözlemlemiştir. (Aktaran: Morgan ve Fluker, 2006: 155-156).

Daha deneyimli olan insanlar daha özel turistik etkinliklerde yer alırlar, bu tip etkinliklerde kendilerinde daha fazla yeterlik hissederler. Ayrica acemi ya da uzman olsalar da, bu etkinliğin sonucu olumlu ise kendilerini daha yeterli hissederler. Etkinlikte başarılı olmanın, üst düzey beceriye bağlı olduğu bazı durumlarda, deneyim ve yeterlik önemli olmaktadır (Pomfret, 2006: 118).

Iso-Ahola ve diğerlerinin (1988: 34) kaya tırmanıcılarının üzerinde yaptığı çalışmada, insanların algıladıkları yeterlik, öz-saygı ve deneyimin birbirine bağlı olduğu tespit edilmiştir. Algılanan yeterlik iki kategoride incelenmektedir. Bunlardan ilki biriken deneyimlerin sonucunda elde edilen 'genel algılanan yeterlik', diğeri ise yeni deneyimlerin sonunda elde edilen 'spesifik algılanan yeterliktir'(Aktaran: Page vd, 2005: 382). Dağcılarla tırmanış gününden bir gün önce ve sonra görüşülmüsstür. Bu dağcıların başarılı bir tırmanışın ardından, tırmanış yetenekleri ile ilgili yüksek öz-yeterlik ve öz-güven gösterdikleri, ayrıca öz-yeterliğin kaya tırmanışı deneyim derecesiyle ilgili olmadığı gözlemlenmiştir. Buna ilaveten tecrübeli dağcılar genel algılanan yeterlik derecelerini yükseltmişlerdir. Bu bulgular diğer turizm türlerine de uygulanabilmektedir. Örneğin, acemi yamaç paraşütçüleri kırmızı ya da siyah gökyüzü olduğunda, kendilerini kâfi derecede yeterli hissetmeden uçmak istemezler. Yamaç paraşütünde yeni olan kişi belli aşamalardan geçip başlangıçta iyi bir eğitim aldıktan sonra çift uçuştan yalnız planörcülüğe doğru ilerler. Pilot ehliyetini aldıktan sonra uzman durumuna tam olarak geçmiş olmaktadır (Swarbrooke vd, 2003: 80).

Şekil 4. Riskli Sporların Davranışsal Unsurları

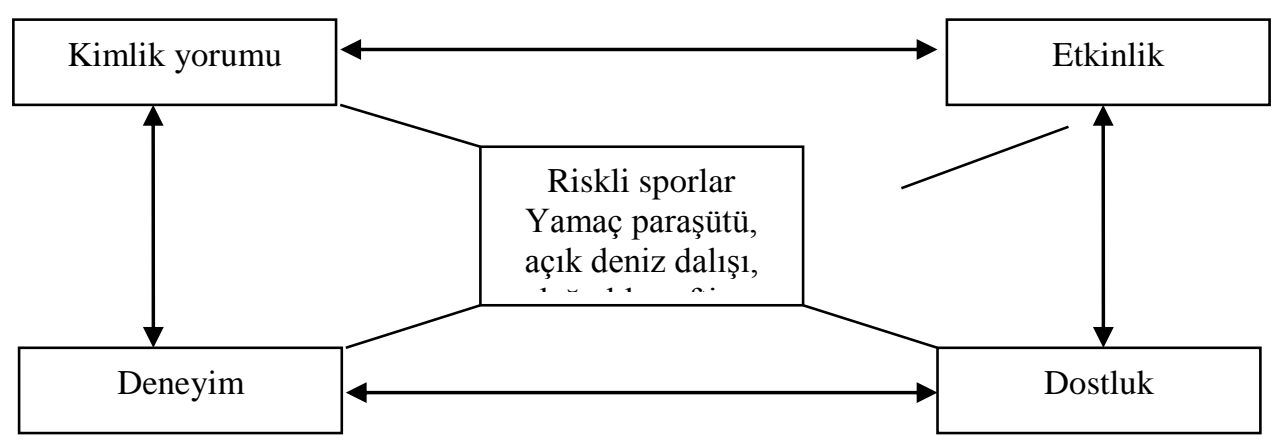

Kaynak: Swarbrooke, John, Beard, Colin, Leckie, Suzanne and Pomfret, Gill (2003). Adventure Tourism: The New Frontier. USA: Elsiver Science Ltd, P: 80.

Şekil 4'te kişileri riskli sporlar yapmaya yönelten dört temel güdü gösterilmektedir. Bunlar (Swarbrooke vd, 2003: 81): 
- Kimlik Yorumu: İnsanlar riskli sporlara; kişisel gelişimlerini sağlamak ve yeni bir kimlik edinmek için katılırlar.

- Etkinlik: Riskli sporlarda bireysel gelişme, uzmanlıkla ve yükselen standartlarla mümkün olacaktır. Bu unsurlar kişilerin etkinliğinin ya da yeteneğinin sonucudur.

- Dostluk: Macera sporlarına katılım sürdürülerek, insanlar dostluk ve bir grubun parçası olma duygusunu yaşamaktadır. $\mathrm{Bu}$ etkinlikle yoğun katılımla, uzmanlık ve gruptaki rol kesinleştirilir. Gerçekleşen bu sonuç, olağan günlük yaşam ve olağan dışı riskli sporlara katılım arasındaki kesin ayrımdır.

- Deneyim: Riskli spor katılımları performans ve deneyimin derecesini artırmaktadır. Daha sonra katılımcıların spor deneyimlerindeki dikkatleri, riskten dolayı endişelenmek yerine, riski kontrol altına almaya yönelir. Yükselen deneyimle, kişiler macera sporlarından daha fazla zevk almaya başlarlar.

Shoham ve diğerlerinin (2000: 239) geliştirdikleri modelde, yeni turist tipolojisi açıklanmaya çalışılmıştır. Model katılımcıların riskli sporlara sadece daha fazla deneyim, beceri ve yeterlik kazanmak gibi açık sebeplerden değil, ayrıca sosyal ve psikolojik nedenlerden dolayı katılmaya devam ettiklerini göstermektedir. Model, süren riskli sporların tüketiminin altında yatan davranışsal unsurları açıklanmaktadır.

\section{ANTALYA İLİ ÖRNEĞİ}

\section{A. Araştırmanın Konusu}

Türkiye, doğal ve kültürel turistik değerleri dikkate alındığında, yeni turistlerin ilgisini çekme kapasitesine sahip bir ülkedir. Yeni turistlerin eğilimlerine yönelik hizmetlerin artırılması, Türkiye'nin turizm endüstrisinden elde ettiği sosyal ve ekonomik faydaları artıracak bir firsat olarak karşımıza çıkabilir. Günümüzde potansiyel kullanıcılarının tercihlerinin dikkate alınmadığı bir sektör nerdeyse yoktur. Yani; Türkiye'de turizmin tür ve etkinliklerinin zenginleştirilmesi, alternatif turizm alanlarının hizmete sunulması ve tanıtılması; farklı yörelerin ekonomik ve sosyal yönden kalkınması ile sonuçlanabilir.

Araştırmanın konusu; turizm hareketlerini bütün yıla yayarak, daha fazla ekonomik ve sosyal fayda elde etmek amacıyla, Türkiye'de doğal ve kültürel kaynakların daha etkin kullanılmasına olanak tanıyan alternatiflerin ortaya konmasıdır. Araştırmanın teorik kısmında, öncelikle, yeni turistik eğilimler açıklanmaya çalışılmıştır. Araştırmanın analiz kısmında ise, Antalya'ya yaz döneminde gelen turistlerin Türkiye'yi tercih etme nedenleri ortaya konmuştur.

\section{B. Araştırmanın Amacı ve Önemi}

Yeni turistik eğilimler, bireylerin yaşam standartlarının değişmesine, beklentilerin farklılaşmasına ve çevre bilincinin artmasına bağlı olarak çeşitlenmektedir. Genellikle yaz aylarında deniz-kum-güneş üçgeninde gelişen turistik etkinlikler yerini, doğa ile iç içe, farklı seyahat kültürlerini tanımaya eğilim gösteren turistlere bırakmaktadır. Bu yeni tip turizm faaliyetleri çevre ile 
uyumlu tesislerde, bozulmamış ve temiz bir çevrede, aktif bir katılımla gerçekleştirilmektedir.

Kitle turizmine alternatif olarak kültür, tarih, yerel değerler, spor, macera ve eğlence anlayışı temeline dayanan yeni turizm türleri geliştirilmiştir. Bunlar; macera turizmi, ekoturizm, doğa turizmi, niş turizm, sürdürülebilir turizm, duyarlı turizm, kültürel turizm gibi akımlardır. Bu akımlar, hem turistlerin beklentilerine uygun turistik ürün çeşitliliğini sağlamış, hem de yılın belli dönemlerinde yapılan turizm amaçlı seyahatleri bütün yıla yaymıştır.

Günümüzün rekabet şiddeti artan ve olgunlaşmış turizm pazarlarında, seyahat ve turizm pazarlamacılarının, daha yüksek beklentilere sahip, farklılaşmış, eğitimli, duyarlı yeni müşteri tipinin istek ve ihtiyaçlarını karş1layacak, farklı turistik ürünlerle rekabet etmeleri gerekmektedir.

Araştırmanın amac1, Antalya'yı tatil amaçlı olarak tercih eden turist pazarının tercihlerini etkileyen başlangıç noktası niteliğindeki eğilimlerinin belirlenmesidir. Araştırmanın odak noktası; pazar bölümlendirmesi hedefine yönelik, uygun içsel pazarlama faktörü bileşeni olarak, yeni turist tercihleri, diğer bir ifade ile turistlerin seyahatleri sırasında dikkat ettiği temel faktörlerin ortaya konmasidır.

Araştırma sonunda elde edilecek olan veriler, yeni turistlerin profilini, "gezi ilişkili" faktörler olan: etkinlik, merak, tercih, fayda ve tahmin gibi psikografik değişkenlerin satın alma üzerine etkisi ile ilgili literatüre katkıda bulunacaktır.

Araştırmanın problemlerine ilişkin cevap arayacağımız sorular aşağıda belirtilmiştir:

1. Araştırmaya katılanların tercihlerini etkileyen doğal ve kültürel faktörler nelerdir?

2. Araştırmaya katılanların tercihlerini etkileyen bölgesel alt yapı unsurları nelerdir?

Araştırma, turistlerin tercih ettikleri yöresel özellikleri ve bu yörelerdeki temel altyapı özelliklerinin belirlenmesi amacıyla yapılmıştır. Bu nedenle araştırma, tasarım olarak sonuçlandırıcı araştırma yönetimlerinden keşifsel araştırma sınıfına girmektedir. Çünkü, keşfedici araştırmalar; "ilişki bulmaya, durum belirlemeye, okuyucuya bilgi vermeye yönelik araştırmalardır” (Nakip, 2008: 22).

Araştırmamızın, bilimsel bir nitelik kazanması ve hedeflenen amaçlarına ulaşabilmesi için izlenen yol şu şekilde açıklanabilir: (1) yeni turist eğilimleri ile ilgili kapsamlı bir literatür taraması yapılmıştır, (2) Antalya'ya gelen turistlerin eğilimlerini belirlemek amaciyla veri toplamak için anket yöntemi seçilmiş ve araştırmanın ana kütlesi içinde yer alan turistlere uygulanmıştır, (3) elde edilen veriler, bilgisayar ortamında tasnif edilmiş ve çözümlenmiştir. (4) Çözümlemelere bağlı olarak bulgular yorumlanmıştır. 
Araştırmanın evrenini, Antalya'ya (tatil amaçlı) gelen turistler oluşturmaktadır. Ancak, çalışmanın zaman ve bütçe kısıtları nedeniyle sadece Antalya'ya tatil amaçlı gelen turistler araştırma kapsamına alınmıştır. Uygulama alanı olarak Antalya ilinin seçilme nedeni, Antalya'nın sahip olduğu kültürel ve turistik değerler açısından Türkiye'deki en önemli turizm çekim merkezlerinden biri olmasının ötesinde, tatil amaçlı seyahatlerde yerli ve yabancı turistlerce Türkiye içinde en fazla tercih edilen destinasyon olması ve turizm çeşitlerinin çoğunun bu ilde gerçekleştirilmesidir.

Araştırmanın ana çatısını oluşturan birincil verilerin elde edilmesinde kullanılan anket, araştırmacı tarafından ilgili literatür taranarak geliştirilmiştir. Anketin oluşturulmasında, Sung (2000) macera turizmi üzerine yaptığı araştırma, Çakıcı ve Harman'ın (2006) Türkiye'de kuş izleme destinasyonları üzerine yaptıkları gerçekleştirilen araştırması incelenmiştir. Uygulamada, 400 kullanılabilir anketin verileri kullanılarak çözümlemeler yapılmıştır. Verilerin değerlendirilmesinde günümüzde yaygın olarak kullanılan SPSS 17.0 (Statistical Package for The Social Science) bilgisayar programı kullanılmıştır. Araştırmanın problemlerinde yer alan özelliklere göre istatistiksel farklılaşmalar Bağımsız Örneklem T Testi (Independent Samples T Test) uygulanarak incelenmiştir.

Araştırma, Antalya'ya tatil amaçlı gelen yerli ve yabancı turistlerle sınırlı tutulmuştur. Araştırmanın problemlerinin çözümünde Bağımsız Örneklem, T Testi, Varyans Analizi ve Post Hoc Testlerinden yararlanılmış ve istatistiksel anlamlılık düzeyi 0.05 olarak belirlenmiştir.

\section{B. Araştırmanın Bulguları ve Değerlendirmesi}

Hipotez: Yeni Turist tipinin Antalya'yı Tercih Etmelerinde Etkili Olan Unsurlar arasında farklılaşmalar vardır.

Katılımcıların Antalya'yı tercih etmelerinde etkili olan unsurlar arasında farklılaşmalar olduğunu içeren hipotez analiz edilmiş ve Tablo 1'de görülmektedir.

Tablo 1. Araştırmaya Katılanların Antalya'yı Tercih Etmelerinde Etkili Olan Unsurlar

\begin{tabular}{|c|c|c|c|c|c|c|}
\hline & \multicolumn{2}{|c|}{ Tüm Örnek } & \multicolumn{2}{|c|}{\begin{tabular}{|c|c|}
$\begin{array}{c}\text { Yerli } \\
(n=188)\end{array}$ & $\begin{array}{c}\text { Yabancl } \\
(n=212)\end{array}$ \\
\end{tabular}} & \multicolumn{2}{|c|}{$t$ Testi } \\
\hline & Or. & S.S. & Or. S.S. & Or. S.S. & $\mathbf{t}$ & $\mathbf{p}$ \\
\hline Görmeye değer ilginç yerler & 4,19 & 0,83 & $4,430,66$ & $3,980,90$ & 5,641 & $<, 001$ \\
\hline Özellikli küçük kasabalar (Fethiye, Kemer gibi) & 3,70 & 1,03 & $4,010,90$ & $3,431,05$ & 5,894 & $<, 001$ \\
\hline Tarihi yerlerin varlığ & 3,94 & 1,03 & $4,120,95$ & $3,77,1,07$ & 3,424 & $<, 001$ \\
\hline Milli Park alanlarının varlığ1 & 3,62 & 1,01 & $3,72 \mid 1,02$ & $3,52,1,00$ & 2,025 & $<, 05$ \\
\hline Antika eşya satıcılarının varlığı & 2,88 & 1,16 & $2,851,15$ & $2,911,18$ & $-0,514$ & 0,607 \\
\hline Yerel eğlence olanaklarının varlığı & 3,12 & 1,10 & $3,161,11$ & $3,091,09$ & 0,637 & 0,525 \\
\hline Yerel yeme içme olanaklarının varlığ & 3,43 & 1,06 & $3,34 \mid 1,09$ & $3,501,03$ & $-1,547$ & 0,123 \\
\hline Hatıra eşyası olabilecek yerel el sanatlarının varlığı & 3,00 & 1,15 & $3,091,16$ & $2,921,13$ & 1,446 & 0,149 \\
\hline Denize, göle, nehire yakınlığı & 4,00 & 1,02 & $4,190,97$ & $3,831,03$ & 3,543 & $<, 001$ \\
\hline Temiz hava & 4,24 & 0,91 & $4,510,73$ & $4,010,98$ & 5,673 & $<, 001$ \\
\hline Yol güzergâhı boyu güzel manzara seyri & 3,88 & 1,03 & $4,200,94$ & 13,59 & 6,069 & $<, 001$ \\
\hline
\end{tabular}




\begin{tabular}{|c|c|c|}
\hline Doğayla baş başa kalma & 3,92 & \begin{tabular}{l|l|l|l|l|l|l|}
1,08 & 4,28 & 0,88 & 3,59 & 1,14 & 6,748 & $<, 001$ \\
\end{tabular} \\
\hline Bölge halkının yardım severliği ve misafirperverliği & 3,64 & \begin{tabular}{l|l|l|l|l|l|l|}
1,13 & 3,80 & 1,06 & 3,49 & 1,17 & 2,83 & $<, 05$ \\
\end{tabular} \\
\hline Ulaşım kolaylığı & 4,13 & \begin{tabular}{|l|l|l|l|l|l|l|l|}
0,85 & 4,35 & 0,78 & 3,94 & 0,87 & 4,909 & $<, 001$ \\
\end{tabular} \\
\hline Yolların kalitesi & 3,71 & \begin{tabular}{l|l|l|l|l|l|l|}
1,03 & 3,85 & 1,04 & 3,58 & 1,01 & 2,595 & $<, 05$ \\
\end{tabular} \\
\hline Park olanakları & 3,45 & \begin{tabular}{l|l|l|l|l|l|l|}
1,04 & 3,57 & 1,10 & 3,33 & 0,98 & 2,308 & $<, 05$ \\
\end{tabular} \\
\hline Sürüş Süresi & 3,52 & \begin{tabular}{|l|l|l|l|l|l|l|l|}
2,29 & 3,54 & 1,08 & 3,50 & 2,98 & 0,206 & 0,837 \\
\end{tabular} \\
\hline Yeme-İçme tesislerinin varlığ 1 & 3,93 & \begin{tabular}{l|l|l|l|l|l|l|l|}
0,88 & 4,12 & 0,84 & 3,76 & 0,88 & 4,087 & $<, 001$ \\
\end{tabular} \\
\hline Konaklama tesislerinin varlı̆̆ & 3,99 & \begin{tabular}{l|l|l|l|l|l|l|l|l|l|l|l|l|}
0,92 & 4,15 & 0,88 & 3,84 & 0,93 & 3,416 & $<, 001$ \\
\end{tabular} \\
\hline Ucuzluk & 3,99 & \begin{tabular}{l|l|l|l|l|l|l|l|}
0,97 & 4,27 & 0,80 & 3,75 & 1,04 & 5,504 & $<, 001$ \\
\end{tabular} \\
\hline Turistik eşya satıcılarının varlığı & 3,00 & \begin{tabular}{|l|l|l|l|l|l|l|l|}
1,08 & 2,90 & 1,12 & 3,09 & 1,04 & $-1,766$ & 0,078 \\
\end{tabular} \\
\hline Araba kiralama şirketlerinin varlığ & 2,84 & \begin{tabular}{l|l|l|l|l|l|l|}
1,11 & 2,69 & 1,11 & 2,97 & 1,11 & $-2,526$ & $<, 05$ \\
\end{tabular} \\
\hline Bölgede Macera Seyahati ile ilgili rehberlik hizmetlerinin varlığı & 3,29 & \begin{tabular}{l|l|l|l|l|l|l|}
1,16 & 3,31 & 1,15 & 3,27 & 1,16 & 0,347 & 0,729 \\
\end{tabular} \\
\hline Seyahat acenteleri tarafindan organize edilmiş turların varlığ 1 & 3,07 & \begin{tabular}{l|l|l|l|l|l|l|l|l|}
1,10 & 3,12 & 1,12 & 3,03 & 1,08 & 0,763 & 0,446 \\
\end{tabular} \\
\hline Kişiye özel tur hazırlayan seyahat acentelerinin varlığ & 2,93 & \begin{tabular}{|l|l|l|l|l|l|l|l|l|l|l|l|l|}
1,14 & 2,90 & 1,11 & 2,94 & 1,18 & $-0,341$ & 0,733 \\
\end{tabular} \\
\hline Doğal yaşamı görme & 4,18 & \begin{tabular}{l|l|l|l|l|l|l|l|}
0,86 & 4,39 & 0,78 & 3,98 & 0,88 & 4,937 & $<, 001$ \\
\end{tabular} \\
\hline Doğal yaşamı fotoğraflama & 4,09 & \begin{tabular}{l|l|l|l|l|l|l|l|}
0,91 & 4,28 & 0,88 & 3,91 & 0,90 & 4,166 & $<, 001$ \\
\end{tabular} \\
\hline Bölgede güvenlik hizmetleri varlığı & 4,19 & \begin{tabular}{l|l|l|l|l|l|l|l|l|l|l|}
0,83 & 4,35 & 0,80 & 4,05 & 0,82 & 3,659 & $<, 001$ \\
\end{tabular} \\
\hline Bölgede sağlık hizmetleri varlığı & 4,32 & \begin{tabular}{l|l|l|l|l|l|l|l|}
0,78 & 4,47 & 0,69 & 4,19 & 0,84 & 3,612 & $<, 001$ \\
\end{tabular} \\
\hline Bölgede bankacılık (24 saatlik) hizmetleri varlığı & 3,87 & \begin{tabular}{ll|l|l|l|l|l|l|}
1,06 & 4,11 & 1,00 & 3,66 & 1,07 & 4,286 & $<, 001$ \\
\end{tabular} \\
\hline
\end{tabular}

$\mathrm{T}$ testi sonuçlarına göre; görmeye değer ilginç yerler, özellikli küçük kasabalar (Fethiye, Kemer gibi), tarihi yerlerin varlığı, Denize, göle, nehire yakınlığı, Temiz hava, Yol güzergâhı boyu güzel manzara seyri, Doğayla baş başa kalma, Ulaşım kolaylığı, Yeme-İçme tesislerinin varlı̆̆ 1 , Konaklama tesislerinin varlığı, Ucuzluk, Doğal yaşamı görme, Doğal yaşamı fotoğraflama, Bölgede güvenlik hizmetleri varlığı, Bölgede sağlık hizmetleri varlığı, Bölgede bankacılık (24 saatlik) hizmetleri varlığı unsurlarında çok büyük farklılaşmaların olduğu görülmektedir. Milli Park alanlarının varlığı, Bölge halkının yardım severliği ve misafirperverliği, Yolların kalitesi, Park olanakları, Araba kiralama şirketlerinin varlığı unsurlarında önemli farklılaşma bulunmuştur.

\section{SONUÇ}

Uluslararası turizm pazarı, dış çevre koşullarından yoğun bir şekilde etkilenmektedir. Gelişmiş ülkelerdeki refah düzeyinin yükselmesi, boş zaman artışı, kişilerin seyahat konusunda deneyim kazanmaları ve sosyo-demografik yapılarının değişmesi, seyahat pazarında yeni turistik eğilimlerin ortaya çıkmasına neden olmuştur.

Aktif genç nüfus artışı, geç evlenme yaşı, birden fazla gelire sahip ailelerin sayısındaki artış, çocuksuz aileler ve yalnız yaşayan yetişkin sayısındaki artış gibi değişimlerin gözlemlendiği, sosyo-demografik yapı, seyahat ve boş zaman talebinde önemli değişiklere neden olmaktadır. Bunun sonucunda oluşan turist tiplerinin ve ihtiyaçlarının çeşitliliği, daha özellikli seyahat türlerinin ve etkinliklerinin ortaya çıkmasına neden olmaktadır.

Tüketicilerin tatmin düzeyinin büyüyen önemi, yeni boş zaman modelinin temellerini, aktif katılımlı etkinlerin oluşturduğu seyahatlere doğru değiştirmiştir. Pazar, çeşitli etkinliklerin bulunduğu, özel amaçlı boş zaman seyahatlerini talep etmektedir. Turizm endüstrisi, pasif tatil anlayışının yerini alan bu yeni eğilime 
doğru kayışı göz ardı etmemelidir. Bu yeni yapıc1, ödüllendirici, onarıc1 rekreasyon fikri en az eğlence için rekreasyon fikri kadar önemlidir.

Yeni turistik eğilimlerle birlikte aktif tatil seçeneklerinin artışı, gerekli teçhizat üretiminin hızl büyümesi ve dolayısıyla tur operatörlerinin ve seyahat acentelerinin ürün çeşitliliğinin artmasına yol açmıştır. Bu sebeple tüm pazara hitap etmek yerine yöresel doğal ve kültürel değerlere odaklanmış, yöresel altyap1 özelliklerinin de etkileyici faktör olarak değerlendirildiği spesifik küçük Pazar gruplarına hitap etmek yerinde olacaktır.

Kitle turizmine alternatif olarak geliştirilen kültür, tarih, yerel değerler, spor, macera ve eğlence anlayışı temeline dayanan; macera turizmi, eko turizm, doğa turizmi, niş turizm, sürdürülebilir turizm, duyarlı turizm, kültürel turizm gibi akımlar, turistlerin beklentilerine uygun turistik ürün çeşitliliğini sağlamıştır. Ayrıca yılın belli dönemlerinde yapılan turizm amaçlı seyahatleri bütün yıla yaymıştır. Heyecan, yeni deneyimler, dinamik bir tatil firsatı, farklı yaşam biçimlerini tanıma gibi çekiciliklerle, günlük yaşantılarının monotonluğundan kaçmak isteyenlere yeni öncelikler kazandırmaktadır. Günümüzün rekabet şiddeti artan pazarlarında, seyahat ve turizm pazarlamacılarının, daha yüksek beklentilere sahip, farklılaşmış, eğitimli, duyarlı yeni turist tipinin istek ve ihtiyaçlarını karşılayacak, farklı turistik ürünlerle rekabet etmeleri gerekmektedir.

Araştırmada temel olarak Türkiye'de turizmin çeşitlendirilmesine ve tüm yıla yayılmasına olanak tanıyacak etkinliklerin hangi yöresel altyapılar ile desteklenmesi gerektiği vurgulanmaya çalışılmıştır. Bu amaç, hem ulusal turizm politikamız hem de Dünya Turizm Örgütünün hedefleri ile paralellik göstermektedir. Teknolojik gelişmelerin sağlık ve finans sektöründe uygulanması analize göre yerinde olacaktır.

Turizmin çeşitlendirilmesine olanak tanıyacak özgün turistik ürünlerin geliştirilmesinde, turizmin etkinliğini artıracak çevresel faktörlerin korunmasında, turizm potansiyelinden maksimum düzeyde yararlanılmasında, potansiyel yeni turist profilinin ve beklentilerinin tespit edilmesi önem taşımaktadır. Bu nedenle, yöresel kaynaklardan ekonomik değer yaratacak şekilde faydalanmayı yollarını belirlemeyi hedefleyen, turizm türleri konusunda yapılan araştırmalarda, potansiyel tüketici profilinin ve tercihlerinin belirlenmesi fayda sağlayacaktır.

$\mathrm{Bu}$ araştırma sonucunda Antalya ve çevresini ziyaret eden yerli ve yabancı turistlerin, o yörede gerçekleştirilebilecek turizm etkinliklerine katılım olasılıkları yüksektir. Antalya ve çevresinde, doğal ve kültürel alanlardan maksimum düzeyde yararlanmak üzerine pek çok çalışma yapılmaktadır. Ancak günümüzde, bu bölgenin mevcut potansiyeli etkin olarak kullanılmamakta; yapılan turizm etkinlikleri av turizmi ile çevresindeki akarsulara, köylere, yaylalara ve ormanlık alanlara yapılan düzensiz turlarla sınırlı kalmaktadır. Bu sebeple, turizm hareketliliğinin ağırlıklı olarak yaz aylarında deniz-güneş-kum üçlüsüne dayalı olarak kıyı kesimde gerçekleştiği görülmektedir.

Turizm etkinliklerinin çeşitliliğinin artırılması potansiyel turistlerin farklı beklentilerinin daha etkin karşılanmasını sağlayarak, hem müşteri bağl1lığını 
artıracak hem de turistik hareketliliğin kıyılardan iç bölgelere doğru kaymasını sağlayarak bölge ekonomisine katkıda bulunacaktır.

Sonuç olarak Türkiye'nin önemli turizm bölgesinde yer alan Antalya'ya gelen turistlerin eğilimleri daha deneyimli, bağımsız, değişikliklere açık olan ve yenilik arayan 'yeni turist' karakteristiğine uymaktadır. Antalya tarihsel, kültürel ve doğal özellikleri ile rekreasyon etkinlikleri için uygun potansiyele sahiptir. Bu özelliklerden yararlanılması, Türkiye'de turizmin çeşitlendirilmesine ve farklı mevsimlere yayılmasina katkıda bulunacaktır.

Ekonomik sosyal, kültürel pek çok yararı olan turizm sektörü, aşırı doğal kaynak kullanımı nedeniyle, doğal alanların ve tarihsel değerlerin tahrip edilmesine yol açabilir. Bu bağlamda, turizm potansiyelinin temelini oluşturan doğal, kültürel ve tarihi değerlerin uzun vadede kullanılabilmesi için ilgili disiplinler tarafından kapsamlı bir turizm envanteri çıkarılması önem taşımaktadır. $\mathrm{Bu}$ envanterde, yörenin mevcut turist profilinin eğilimlerinden faydalanılarak; doğal, kültürel ve tarihi kaynakların etkin kullanımını artırmak için geliştirilecek turizm türleri belirlenmelidir.

Özellikle gelişmekte olan ülkelerin hükümetleri, ulusal ve uluslar arası sivil toplum örgütleri ve turizm işletmeleri macera turizminin tanıtımına öncelik vermelidir. Çünkü turizmden karşılıklı fayda sağlanması; turist, yerel halk, ilgili kurum ve kuruluşların birlikte çalışması ile mümkün olacaktır.

\section{KAYNAKÇA}

Bentley, T., Page, S.J. and Laird, I. (2003). Managing Tourist Safety: The Experience of the Adventure Tourism Industry. (Edited by Jeff Wilks and Stephen J. Page). Managing Tourist Health and Safety in the New Millenium. UK: Elsevier Science Ltd, 85-97.

Buckley, R. (2007). Adventure Tourism Products: Price, Duration, Size, Skill, Remoteness. Tourism Management. Vol. 28, 1428-1433.

Cater, C. I. (April, 2006). Playing with risk? Participant Perceptions of Risk and Management Implications İn Adventure Tourism. Tourism Management, Vol. 27, Iss. 2, 317-325.

Deniz, A. ve Erciş, A. (2008). Kişilik Özellikleri ile Algılanan Risk Arasındaki İlişkilerin İncelenmesi Üzerine Bir Araştırma. Atatürk Üniversitesi İktisadi ve İdari Bilimler Dergisi, Cilt 22, Say1 2, 301-330.

Elsrud, T. (2001). Risk Creation In Travelling: Backpacker Adventure Narration. Annals of Tourism Research, Vol. 28, No. 3, 597-617.

Ferguson, S. and Todd, S. (2005). Acquiring Status Through the Comsumption of Adventure Tourism (Edited by Michelle Aicken). Taking Tourism To The Limits: Issue, Concepts And Managerial Perspectives (First Edition). UK: Elsevier Science Ltd, 149-155.

Garda, B. (2014). Macera Turizmi Pazarlaması. Konya: Çizgi Kitabevi.

Gyimothy, S. and Mykletun, R. J. (2004). Play In Adventure Tourism: The case of Arctic Trekking. Annals of Tourism Research, Vol. 31, No. 4, 855-878.

Hill, B.J. (Sep 1995). A Guide to Adventure Travel. Parks\&Recreation Academic Research Library. Vol 30, Iss 9, 56- 65.

Kane, M. J. and Tucker, H. (2004). Adventure Tourism The freedom to play with reality. Tourist Studies, Vol 4(3), 217-234.

Lepp, A. and Gibson H. (2008). Sensation Seeking And Tourism: Tourist Role, Perception Of Risk And Destination Choice. Tourism Management. Vol. 29, 740-750.

Loverseed, H. (1997). Market Segments: The Adventure Travel Industry in North America. Travel \& Tourism Analyst. No: 6, 87-104. 
Morgan, D. and Fluker, M. (2006). Risk Management For Australian Commercial Adventure Tourism Operations. (Edited by Yoel Mansfeld ve Abraham Pizam). Tourism, Security And Safety: From Theory To Practice. Oxford UK: Elsevier Ltd, 153-168.

Nakip, M. (2008). Pazarlama Araştırmalarına Giriş. Ankara: Seçkin Yayıncılık.

Pearce, D. G. (1992) Alternative Tourism: Concepts, Classifications and Questions (Edited by Valene L. Smith and William R. Eadington). Tourism Alternatives: Potentials and Problems in the Development of Tourism USA: International Academy for the Study of Tourism, 13-31.

Page, S. J., Bentley, Tim A. and Walker, L. (2005). Scoping the nature and extent of adventure tourism operations in Scotland: How safe are they?. Tourism Management, Vol. 26, 381397.

Pomfret, G. (February 2006). Mountaineering adventure tourists: a conceptual framework for research. Tourism Management. Vol 27, Iss 1, 113-123.

Richards, G. and Wilson, J. (2006). Youth and Adventure Tourism (Edited by Dimitrios Buhalis, Carlos Costa). Tourism Business Frontiers: Consumers, Products and Industry (First Edition). Oxford UK: Elsevier Ltd, 40-48.

Ryan, C. (2002). Equity, Management, Power Sharing and Sustainability- Issues of the 'New Tourism'. Tourism Management. Vol 23, 17-26.

Ryan, C. (2003). Risk Acceptance in Adventure Tourism. (Edited by Jeff Wilks and Stephen J. Page). Managing Tourist Health and Safety in the New Millenium. UK: Elsevier Science Ltd, 55-66.

Schott, C. (2007). Selling Adventure Tourism: a Distribution Channels Perspective. International Journal of Tourism Reseach, Vol. 9, 257-274.

Swarbrooke, J., Beard, C., Leckie, S. and Pomfret, G. (2003). Adventure Tourism: The New Frontier. USA: Elsiver Science Ltd.

Sung, H. H.(May 2000). An Analysis of The Adventure Travel Market: From Conceptual Development to Market Segmentation, $\mathrm{PhD}$, Purdue University.

Sung, H. H., Morrison, A. M.,Hong, Gong-Soog and O’Leary, J. T.(February, 2001). The Effects Of Household and Trip Characteristics on Trip Types: A Consumer Behavioral Approach for segmenting the U.S. Domestic Leisure Travel Market. Journal of Hospitality \& Tourism Research, Vol. 25, No. 1, 46-68.

Sung, H. H., Morrison, A. M. and O'Leary, J. T.(Ocak 1996). Definition of Adventure Travel: Conceptual Framework for Emprical Application from the Providers' Perspective. Annual Society of Travel and Tourism Educators Conference in Ottawa, Canada http://www.hotel-online.com Erişim Tarihi: 23.12.2005

Tangeland, T. and Aas, Q. (2009). Household Composition And The İmportance Of Experience Attributes Of Nature Based Tourism Activity Products- A Norwegian Case Study Of Outdoor Recreationists. Tourism Management, Vol. 32, 822-832.

Tanrısevdi, A. (2009). Türk Özel İlgi Gezginleri Sansasyon Arama Özelliği Sergilemekte midir? Ege Akademik Bakış. Cilt 9, Sayı 4, 1313-1340.

Weber, K. (2001). Outdoor Adventure Tourism A Review of Research Approaches. Annals of Tourism Research, Vol. 28, No. 2, 360-377.

Weed, M. (2009). Progress In Sports Tourism Research? A Meta-Review and Exploration Of Future. Tourism Management, Vol. 30, 615- 628.

Williams, P and Soutar, G. (September 2005). Close to "Edge": Critical Issues for Adventure Tourism Operators. Asia Pacific Journal of Tourism Research, Vol. 10, No. 3, 247-261.

Willig, C. (2008). A Phenomenological Investigation of Taking Part in 'Extreme Sports'. Journal of Health Psychology. Vol. 13, No. 5, 690-702. 


\section{SUMMARY}

Economic, politic, legal and social aspects has experienced a great deal of differences in the twenty-first century. With the development of information technologies and transportation services changed every things: like individuals, society and the interaction between countries has intensified. Individuals' lifestyles, tastes and habits, values and cultural activities varies with the global interaction .

In today's economy, worldwide international tourism industry plays an active role and it is changed the behavior and choice of new tourists'. Because of increasing income level of individuals, welfare level and parallel to the changing philosophy of life. The new tourists have lots of motivations and also these motivations vary between tourists purchasing the 'same' experience.

Motivations could include everything from improve status to escaping from everyday life or from meeting people to testing oneself to improving one's health. These are the main factor that influences tourism industry. At the end of this transformation tourism increase its importance for the country. Therefore, to examine new tourist style in international tourism is important .

The main purpose of this study clear the new style of the international tourist and to search the literature about the preferences of the new tourist type.In this article it has been determind the basic needs of tourists in the touristic areas. First, it was determined the characteristics of tourists. Finally, it was seen that the new tourist prefences adds a new level of mentality to new tourism marketing. 